Creative commons User License: CC BY-NC-ND

Abstracted by: EBSCOhost, Electronic Journals Service (EJS),

Google Scholar, Directory of Open Access Journals (DOAJ),

Journal Seek, Scientific Commons,

Food and Agricultural Organization (FAO), CABI and Scopus
Journal of Agricultural Extension

Vol. 21 (3) October, 2017

ISSN(e): 24086851; ISSN(Print); $1119944 X$

http://journal.aesonnigeria.org

http://www.ajol.info/index.php/jae

Email: editorinchief@aesonnigeria.org

\title{
Contributions of Rural Women Entrepreneurs in Non-Farm and Off-Farm Enterprises of Households Poverty Reduction in Abia State
}

https://dx.doi.org/10.4314/jae.v21i3.14

Obinna Leo. 0

Department of Rural Sociology and Extension

Michael Okpara University of Agriculture, Umudike

Email: obinna.leo@mouau.edu.ng and obinna.leo2@gmail.com;

Phone: 08032698560

\section{Onu Samson Ejike}

Department of Rural Sociology and Extension

Michael Okpara University of Agriculture, Umudike

Email: samsononu@gmail.com and samsononu@yahoo.com

Phone: 08134870488

Abstract

The study assessed the contributions of rural women entrepreneurs in non-farm and off-farm enterprises to household poverty reduction in Abia State, Nigeria. The specific objectives were to: examine the socioeconomic characteristics of the respondents, identify the non-farm and off- farm activities, ascertain the extent of contribution, and determine the contribution of income from non- farm and off- farm activities to poverty reduction respectively. A sample size of 180 respondents selected via multi stage sampling technique was used. Data generated via the use of questionnaire and were analyzed using both descriptive and inferential statistics respectively. Results showed a mean age of 46 years, $66.7 \%$ were married, $93.8 \%$ were literates with a mean monthly income of $\$ 23,444.00$ and a mean household size of 5 persons respectively. Farm -gate trading (38.9\%), agro- processing (16.7\%), general merchandise (11.1\%), restaurants/ bars (16.7\%), civil servants (4.4\%), and others (5.6\%) were identified as non-farm and off- farm enterprises. Income from non- farm and off- farm enterprises contributed to a very high extent and high extent ( $X=4.7$, and4.5) and ( $X=4.4,3.8$ and 3.7) in household health care and feeding respectively and improved housing, children's education and clothing respectively. It further contributed moderately $(X=3.3),(X=2.7), \quad(X=$ 2.6) and $(X=3.0)$ in personal savings, social obligations, extended family responsibility and investment into agriculture respectively. Restaurant/bar(\$708.00/day), general merchandise (\$618.00/ day), agro-processing ( $\$ 596.00 /$ day), civil servants( $\$ 557.00 /$ day), and, teaching/pasturing ( $\$ 535.00 / d a y)$, among others contributed to poverty reduction in the study area. The Tobit result showed that age $\left(X_{1}=9.07^{* *}\right)$, household size $\left(X_{4}=4.064^{* *}\right)$ education $\left(X_{3}=7.029^{* * *}\right)$ and income $\left(X_{6}=5.202^{* * *}\right)$ respectively, significantly influenced contribution to household welfare. Business experience $\left(X_{5}=2.02^{* *}\right)$ 
Creative commons User License: CC BY-NC-ND

Abstracted by: EBSCOhost, Electronic Journals Service (EJS),

Google Scholar, Directory of Open Access Journals (DOAJ),

Journal Seek, Scientific Commons,

Food and Agricultural Organization (FAO), CABI and Scopus
Journal of Agricultural Extension

Vol. 21 (3) October, 2017

ISSN(e): 24086851; ISSN(Print); $1119944 X$

http://journal.aesonnigeria.org

http://www.ajol.info/index.php/jae

Email: editorinchief@aesonnigeria.org

significantly influenced contribution to household welfare. The study recommends that Extension Agents should encourage rural women to form co-operatives which will enable them obtain loans from financial firms, this will increase their investment abilities into non- farm and off- farm ventures which supplement income from farming thereby reducing poverty mostly in the study area.

Key words: women entrepreneurs, poverty reduction, non- farm and off- farm enterprises

\section{Introduction}

Non-farm and off-farm activities play important role in providing supplementary employment to small and marginal farm households thereby reducing income inequalities and poverty among rural households (Haggblade et al., 2007). Similarly, Reardon et al., (2007) reported that income from rural non-farm enterprises greatly exceeded the value of farm wage income mostly in Sub - Saharan Africa. Reliance on agriculture tends to diminish continuously due to population growth, lack of credit facilities to poor rural farmers, coupled with high cost of agro- inputs and high cost of production. Kwon, Orazem and Otto (2006) equally, reported inadequacy of farm income and high incidence of poverty among small - scale farmers. Saliu and Adedayo (2010) supported the view as they reported that vast majority of rural families in Nigeria who are basically farmers but could not meet the global challenges in the quest to ameliorate rural poverty. Therefore, resorted to diversify into non- farm income generating services as coping strategy. Haggblade et al., (2007) equally, noted that non- farm activities were positively associated with income and wealth creation in rural areas that were seen to offer a pathway out of poverty. On the same note, Olanipekun and Kuponiyi (2010) observed that non- farm income generating enterprises have been identified to have positive correlation with financial saving, social contacts, education and local capacity building opportunities among the rural poor in Africa. On that note, Haggblade et al., (2007) described rural nonfarm enterprises to include all economic activities in rural areas except agriculture, livestock, fishing and hunting. Similarly, Obinna (2014) described off- farm activities to constitute of all the income generating activities that afarmer embarks on in addition to farming. Therefore, off- farm activities contribute to household food security by providing cash for food and other household purchases and equally, in agricultural assets acquisition. Babatunde et al (2010) also, reported that off- farm activities were risks minimizing strategies that safeguarded farmers against crop and market failures. It has been asserted that about $70 \%$ of Nigerian's poor live in rural areas and are largely dependent on agriculture or agriculture related activities for livelihood (Ekong, 2010). It has been equally observed that about $60-80 \%$ of the workload in agriculture was undertaken by women, coupled with $80-90 \%$ of their time spent on household chores such as fetching water, firewood, taking care of the young, elderly and sick members of the household among others ( Ekong, 2010). On the same note, Saliu and Adedayo (2010) reported that vast majority of rural households in Nigeria mostly female headed households are basically farmers who could not meet the basic household needs in order to ameliorate rural poverty and ensure household food security. Therefore, most of them try to diversify into non - 
Creative commons User License: CC BY-NC-ND

Abstracted by: EBSCOhost, Electronic Journals Service (EJS), Google Scholar, Directory of Open Access Journals (DOAJ), Journal Seek, Scientific Commons,

Food and Agricultural Organization (FAO), CABI and Scopus
Journal of Agricultural Extension

Vol. 21 (3) October, 2017

ISSN(e): 24086851; ISSN(Print); 1119944X

http://journal.aesonnigeria.org

http://www.ajol.info/index.php/iae

Email: editorinchief@aesonnigeria.org

farm and off - farm income generating services as coping strategy. On the other hand, Streeten (1979) defined poverty as being unable to meet "basic needs". Basic needs refer to the physical (food, health care, education, shelter, among others) and non- physical requirements of meaningful "life". It was based on that note, that The World Bank (1996) defined poverty as the inability to attain a minimum standard of living, measured in terms of basic consumption needs or the basic income to satisfy such needs. The expenditure (\$2.25 per a day as of 2005) necessary to attain this minimal standard is the basis used to define the poverty line. It was in the light of the above that the study sought to assess the contribution of rural- women entrepreneurs in non- farm and off- farm enterprises to household poverty reduction in Abia State. The study was guided by the following specific objectives, which included to:

(i) describe the socio - economic characteristics of the respondents;

(ii) identify the non - farm and off - farm activities engaged upon by the respondents;

(iii) ascertain the extent of contribution to household welfare from non- farm and off- farm activities of the respondents;

(iv) determine the contribution of non- farm and off- farm income to poverty reduction in the study area.

$\mathrm{HO}_{1}$ : There is no significant relationship between selected socio - economic characteristics of the respondents and their level of contribution to household welfare in the study area.

\section{Methodology}

The study was conducted in Abia State. The State is located within Latitude $40-70^{\circ}$ $\mathrm{N}$ and Longitude $7-8^{\circ} \mathrm{E}$ (NRCRI, 1990). It has a total landmass of about $5833.77 \mathrm{KM}^{2}$ with a population of $2,833.99$ out of which $1,434,193$ were males and $1,399,806$ females with a population density of 486 persons/ $\mathrm{Km}^{2}$ ( NPC, 2007). About, $49.3 \%$ Abians were actively employed out of which $42.6 \%$ were in agriculture or agriculture related, and $62.3 \%$ dwelled in the rural areas (Ekong, 2010). A multi- stage sampling technique was adopted in generating a sample size of 180 respondents used for the study. Firstly, Abia State was stratified into the three major Agricultural Zones, namely: Ohafia, Umuahia and Aba Agricultural Zones respectively. Secondly, 4 Agricultural Blocks were randomly selected from each of the 3 Agricultural Zones to give 12 Agricultural Blocks. Thirdly, 3 Agricultural Circles were randomly selected from each of the 12 Agricultural Blocks to give a total of 36 Agricultural Circles. Fourthly, 5 respondents were randomly selected from each of the 36 Agricultural Circles with the assistance of the Extension Agents (EAs) to give a total of 180 respondents. Primary data were generated via the use of structured questionnaire and scheduled interviews. Data generated were analyzed through the use of descriptive and inferential statistics, which included frequency count, percentages, means, pooled means and Tobit regression analysis respectively.

The Tobit model is expressed as follows:

$$
\begin{aligned}
& P_{i}=X_{i} \beta+e_{i} \text { if } P_{i}>P_{i}{ }^{*} \\
& O=X_{i} \beta+e_{i f f} P_{i} \leq P_{i}^{*} \\
& i=1,2,3 \ldots \ldots \ldots 6 \ldots(3.1) \\
& \text { Where } P_{i} \text { is the dependent variable. }
\end{aligned}
$$


Creative commons User License: CC BY-NC-ND

Abstracted by: EBSCOhost, Electronic Journals Service (EJS),

Google Scholar, Directory of Open Access Journals (DOAJ), Journal Seek, Scientific Commons,

Food and Agricultural Organization (FAO), CABI and Scopus

\section{Journal of Agricultural Extension}

Vol. 21 (3) October, 2017

ISSN(e): 24086851; ISSN(Print); 1119944X

http://journal.aesonnigeria.org

http://www.ajol.info/index.php/jae

Email: editorinchief@aesonnigeria.org

$\mathrm{Pi}=$ contribution to household welfare

$X_{i}=$ is a vector of explanatory variable, $\beta$ is a vector of unknown coefficient and $e_{i}$ is an independently distributed error term.

The explanatory variables specified as determinants of household welfare contribution were:

$\mathrm{X}_{1}=$ Age (in years)

$\mathrm{X}_{2}=$ Marital status ( $\mathrm{D}=1$ if married, 0 if otherwise)

$\mathrm{X}_{3}=$ Education (years of schooling)

$\mathrm{X}_{4}=$ Household Size (number of persons)

$\mathrm{X}_{5}=$ Business Experience (in years)

$\mathrm{X}_{6}=$ Monthly income (in Naira)

\section{Results and Discussion}

\section{Socio - Economic Characteristics}

The socio economic characteristics of the respondents are as presented in Table 1. Table1 shows the mean age of the respondents as about 46 years and about $66.7 \%$ married, $11.1 \%$ single, $2.8 \%$ widowed and $8.3 \%$ divorced / separated respectively. Table 1 equally, shows that about $93.8 \%$ of the respondents were literates and $50 \%$ were primary education completed with a mean household size of about 5 persons and 18 yearsof mean years of business experience. Table 1 also shows 23,444.44 as a mean monthly income to the respondents. The implication of the finding is that with a mean age of about 46 years of the respondents, confirms the fact that the women were still young and with a high proportion $(66.7 \%)$ being married with a mean household size of about 5 persons indicates that the women were diversifying into other sources of livelihood other than farming in order to supplement the meagre resources from farming. This corroborates Olanipekun and Kuponiyi (2010) who asserted that vast majority of rural families in Nigeria are basically practicing farmers who cannot meet their needs therefore, they diversity into non - farm income generating activities as coping strategy. 
Creative commons User License: CC BY-NC-ND

Abstracted by: EBSCOhost, Electronic Journals Service (EJS),

Google Scholar, Directory of Open Access Journals (DOAJ),

Journal Seek, Scientific Commons,

Food and Agricultural Organization (FAO), CABI and Scopus
Journal of Agricultural Extension

Vol. 21 (3) October, 2017

ISSN(e): 24086851; ISSN(Print); 1119944X

http://journal.aesonnigeria.org

http://www.ajol.info/index.php/jae

Email: editorinchief@aesonnigeria.org

Table 1: Socio - economic characteristics of respondents

\begin{tabular}{|c|c|}
\hline & Percentage (\%) $\mathbf{n}=120$ \\
\hline \multicolumn{2}{|l|}{ Age in Years } \\
\hline $20-30$ & 11.11 \\
\hline $31-40$ & 22.22 \\
\hline $41-50$ & 27.77 \\
\hline $51-60$ & 25.00 \\
\hline$\geq 61$ & 13.89 \\
\hline Mean & 45.6 years \\
\hline \multicolumn{2}{|l|}{ Marital Status } \\
\hline Married & 66.67 \\
\hline Single & 11.11 \\
\hline Widowed & 2.77 \\
\hline Divorced/Separated & 8.33 \\
\hline \multicolumn{2}{|l|}{ Educational Level } \\
\hline No formal Education & 5.56 \\
\hline Completed Primary Sch. & 50.00 \\
\hline Completed Sec. Sch. & 35.56 \\
\hline Tertiary Education & 8.33 \\
\hline \multicolumn{2}{|c|}{ Household Size no Persons } \\
\hline$\leq 2$ & 5.56 \\
\hline $3-4$ & 22.22 \\
\hline $5-6$ & 38.89 \\
\hline 7 \& Above & 33.33 \\
\hline \multicolumn{2}{|c|}{ Mean $=5$ persons } \\
\hline \multicolumn{2}{|c|}{ Years of Business Experience } \\
\hline$\leq 10$ & 33.33 \\
\hline $11-20$ & 27.77 \\
\hline $21-30$ & 16.67 \\
\hline 31 \& Above & 22.22 \\
\hline \multicolumn{2}{|l|}{ Mean $=18$ years } \\
\hline \multicolumn{2}{|l|}{ Monthly income in Naira } \\
\hline$\leq 15,000.00$ & 33.33 \\
\hline $16,000.00-26,000.00$ & 38.89 \\
\hline $27,000.00-37,000.00$ & 16.67 \\
\hline $38,000.00-48,000.00$ & 08.33 \\
\hline $49,000.00$ \& Above & 2.77 \\
\hline 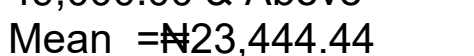 & \\
\hline
\end{tabular}

Source: Field Survey 2016.

Types of non-farm and off-farm activities engaged into by the women entrepreneurs

Types of non-farm and off-farm activities engaged into by the women entrepreneurs in the study area as presented in Table 2 . Table2 shows that farm gate/ petty trading (38.9\%), agro- processing and restaurants/ bar dealers $(16.7 \%)$ respectively constituted about $72.23 \%$ of the non - farm and off- farm activities that the rural 
Creative commons User License: CC BY-NC-ND

Abstracted by: EBSCOhost, Electronic Journals Service (EJS),

Google Scholar, Directory of Open Access Journals (DOAJ),

Journal Seek, Scientific Commons,

Food and Agricultural Organization (FAO), CABI and Scopus

\author{
Journal of Agricultural Extension \\ Vol. 21 (3) October, 2017 \\ ISSN(e): 24086851; ISSN(Print); 1119944X \\ http://journal.aesonnigeria.org \\ http://www.ajol.info/index.php/jae \\ Email: editorinchief@aesonnigeria.org
}

women entrepreneurs engaged into in the study area. Others included: general merchandise trading $(11.1 \%)$, cloth weaving / tailoring $(2.8 \%)$, teaching /pastoring $(1.7 \%)$, traditional midwives / healers $(2.2 \%)$, civil - servants $(4.4 \%)$ and other enterprises $(5.6 \%)$ respectively. The implication of the finding is that a very high proportion $(72.2 \%)$ of the rural women entrepreneurs were involved in mostly agricultural related non- farm and off- farm activities. This corroborates Ekong (2010) who observed that about half $(50 \%)$ of the actively employed Abians dwelling in the rural areas were either involved in agriculture or agricultural related activities.

Table 2: Types of non - farm and off- farm enterprises

\section{Types of off- farm activities and non- farm Percentage (\%)}

\begin{tabular}{lr}
\hline Off- farm Activities & \\
Farm - gate / petty traders & 38.89 \\
Agro - processors & 16.67 \\
Non- farm activities & \\
General Merchandise traders & 11.11 \\
Restaurants / Bar dealers & 16.67 \\
Cloth weaving / Tailoring & 2.77 \\
Teaching / Pastoring & 1.66 \\
Traditional midwives/ healers & 2.22 \\
Civil - servants & 4.44 \\
Other enterprises & 5.56
\end{tabular}

Source: Field Survey 2016.

\section{Extent of Contribution to Household Welfare from the Non-Farm and Off-Farm Activities}

The extent of contribution to household welfare from the non - farm and off-farm activities by the respondents is as presented in table 3 . Table 3 shows that the respondents contributed to a very high extent $(X=4.5)$ and $(X=4.7)$ to household feeding and health care respectively from non- farm and off- farm income. They equally contributed to high extent $(X=3.8),(X=3.7)$ and $(X=4.4)$ in improved housing, children's education and purchase of clothing respectively. Table 3 further shows that the respondents contributed to a moderate extent to personal savings, social obligations, extended family responsibility and investment into agriculture respectively from non- farm and off- farm income. The implication of the finding is that the rural women entrepreneurs spent between 80 and $100 \%$ of their income from non - farm and off- farm activities in household feeding and healthcare. This corroborates Obinna (2014) who observed that women channel more of their earnings towards household consumption than their male counterparts who use theirs for building of houses, buying of cars among other things. 
Creative commons User License: CC BY-NC-ND

Abstracted by: EBSCOhost, Electronic Journals Service (EJS), Google Scholar, Directory of Open Access Journals (DOAJ), Journal Seek, Scientific Commons,

Food and Agricultural Organization (FAO), CABI and Scopus
Journal of Agricultural Extension

Vol. 21 (3) October, 2017

ISSN(e): 24086851; ISSN(Print); 1119944X

http://journal.aesonnigeria.org

http://www.ajol.info/index.php/jae

Email: editorinchief@aesonnigeria.org

Table 3: Contribution of non- farm and off- farm income to household welfare

\begin{tabular}{lc}
\hline Household Welfare & Mean \\
\hline Household feeding & 4.5 \\
Household Healthcare & 4.7 \\
Improved Housing & 3.8 \\
Children's Education & 3.7 \\
Purchase of Clothing & 4.4 \\
Personal Savings & 3.3 \\
Social Obligations & 2.7 \\
Extended Family Responsibility & 2.6 \\
Investment into Agriculture & 3.0 \\
\hline
\end{tabular}

\section{Source: Field Survey 2016}

\section{Contribution of Non- Farm and Off- Farm Income to Poverty Reduction}

The distribution of the respondents according to the contribution of non- farm and offfarm income to poverty reduction is as presented in Table 4. The exchange rate between Nigerian Naira and the American Dollar as at the time of the study was \#500.00 to one American Dollar. Therefore, according to World Bank (2008) which gave the revised figure of 1.25 US Dollar per a day as income as at 2005 purchasing power parity as the poverty line. Therefore, this is taken as the baseline in order to determine how much the women entrepreneurs contributed to poverty reduction in the households in the study area. Table 4 shows that the rural women entrepreneurs who dealt on petty farm gate trading contributed $\$ 460.00$ per day to household upkeep, agro- processors contributed $\$ 596.00$ per a day, general merchandise contributed $\$ 618.00$, restaurants \& bar dealers contributed $\$ 708.00$, cloth weaving and tailoring contributed $\$ 542.00$, teaching / pastoring contributed $\$ 535,00$, traditional midwives/ healers contributed $\$ 487.00$, civil servants contributed $\$ 557.00$ and others contributed $\$ 422.00$ respectively. The findings show that the rural women entrepreneurs contributed substantially to household poverty reduction.

Table 4: Contribution of non- farm and off- farm income to poverty reduction in the study area

\begin{tabular}{|c|c|c|c|c|c|c|c|c|c|}
\hline $\begin{array}{l}\text { Income from non-farm } \\
\text { \& off-farm activities In } \\
\text { naira }\end{array}$ & $\mathbf{F} / \mathbf{G} / \mathbf{T}$ & A/P & $\mathbf{G} / \mathbf{M}$ & $\mathbf{R} / \mathbf{B}$ & $\mathrm{C} / \mathrm{W}$ & $\mathbf{T} / \mathbf{P}$ & $\mathbf{T} / \mathbf{M}$ & $\mathrm{C} / \mathrm{S}$ & $\mathbf{O}$ \\
\hline$\leq 10,000$ & 70 & 40 & 40 & 20 & 60 & 50 & 30 & 50 & 80 \\
\hline $11,000.00-20,000.00$ & 60 & 40 & 50 & 40 & 40 & 60 & 70 & 40 & 60 \\
\hline $21,000.00-30,000.00$ & 30 & 30 & 40 & 60 & 50 & 30 & 20 & 20 & 30 \\
\hline $31,000.00-40,000.00$ & 20 & 40 & 30 & 30 & 20 & 40 & 10 & 20 & 10 \\
\hline $41,000.00-50,000.00$ & - & 20 & 20 & 30 & 10 & - & - & 20 & - \\
\hline $51,000.00 \&$ Above & - & - & - & - & - & - & - & 10 & - \\
\hline Mean Income in Naira & $17,250=$ & $22,861=$ & $23,167=$ & $26,556=$ & $20,333=$ & $20,083=$ & $15,278=$ & $20,889=$ & $15,833=$ \\
\hline Daily Income/30 & $575=$ & $745=$ & $772=$ & $885=$ & $677=$ & $669=$ & $609=$ & $696=$ & $528=$ \\
\hline $\begin{array}{l}\text { Poverty reduction } \\
\text { contribution in } \# \text { / day }\end{array}$ & $\# 460 .=$ & \#596= & $\# 618=$ & $\# 708=$ & $\# 542=$ & $\# 535=$ & $\# 487=$ & $\Uparrow 557=$ & $\# 422=$ \\
\hline
\end{tabular}

Source: Field Survey 2016.

$\mathrm{NB}=\mathrm{F} / \mathrm{G} / \mathrm{T}=$ Farm - gate trading, $\mathrm{A} / \mathrm{P}=$ Agro- processors, $\mathrm{G} / \mathrm{M}=$ General merchandise, $\mathrm{R} / \mathrm{B}=$ Restaurants $/$ bars, $\mathrm{C} / \mathrm{W}=\mathrm{Cloth}$ weaving/ tailoring, $\mathrm{T} / \mathrm{P}=$ Teaching/ Pastoring, $\mathrm{T} / \mathrm{M}=$ Traditional Midwives $/$ healers, $\mathrm{C} / \mathrm{S}=\mathrm{Civil}$ Servants, and $\mathrm{O}=\mathrm{Others}$. 
Creative commons User License: CC BY-NC-ND

Abstracted by: EBSCOhost, Electronic Journals Service (EJS),

Google Scholar, Directory of Open Access Journals (DOAJ),

Journal Seek, Scientific Commons,

Food and Agricultural Organization (FAO), CABI and Scopus
Journal of Agricultural Extension

Vol. 21 (3) October, 2017

ISSN(e): 24086851; ISSN(Print); 1119944X

http://journal.aesonnigeria.org

http://www.ajol.info/index.php/jae

Email: editorinchief@aesonnigeria.org

\section{Factors Influencing the Contribution of Women to Household Welfare}

Table 5 shows that age $\left(X_{1}=9.079^{\star * \star}\right)$, household size $\left(X_{4}=4.064^{\star * \star}\right)$, education $\left(X_{3}=7.029^{* * *}\right)$ and income $\left(X_{6}=5.202^{* * *}\right)$ respectively significantly influenced women contribution to household welfare positively at $1 \%$ alpha level. Table 5 equally, shows that years of business experience $\left(X_{5}=2.398^{* *}\right)$ significantly influenced women contribution to house hold welfare at $5 \%$ alpha level, while marital status ( $\left.\mathrm{X}_{2}=0.896\right)$ had no significant influence over women contribution to household welfare in the study area at $\mathrm{R}^{2}=56.9 \%$. The implication of the finding is that $\mathrm{HO}_{1}$ which stated that there is no significant relationship between some selected socio economic characteristics of the respondents and their contribution to household welfare is hereby rejected and the alternative accepted.

Table 5: Socio- economic variables that influence the contribution of the women entrepreneurs to household welfare.

\begin{tabular}{llll}
\hline Parameter & Estimate & Std. Error & t-value \\
\hline Sex & -.005 & .171 & -.030 \\
Age & .009 & .010 & $9.079^{\star \star *}$ \\
Marital & .156 & .174 & .896 \\
Household & .002 & .030 & $4.064^{\star * *}$ \\
Education & .017 & .016 & $7.029^{\star * \star}$ \\
Business experience & .006 & .016 & $2.398^{\star *}$ \\
Income & 2.387 & .459 & $5.202^{\star * \star}$ \\
Chi - square & $71.577^{\star \star *}$ & & \\
Log likelihood & 34.8879 & & \\
Pseudo R & 0.5687 & & \\
\hline
\end{tabular}

${ }^{\star *} P \leq 5 \%$, *** $P \leq 0.01$

Field Survey, 2016

\section{Conclusion and Recommendations}

Different non- farm and off- farm enterprises engaged into by the rural women entrepreneurs greatly reduced poverty by supplementing the meager income from subsistent farming in the study area. Rural women should be encouraged to form cooperatives that will enable them access loans from banks. All stakeholders in rural and community development should educate the women of the importance of diversifying their source of livelihood instead of depending solely on peasant farming that does not break even in terms of returns. Government should emphasize capacity building of rural women in other ventures including agriculture.

\section{References}

Babatunde, R. O.; Olagunju, F. I.; Fakayode, S. B. and Adejobi, A. O. (2010). Determinants of participation in Off - farm employment among smallholder 
Creative commons User License: CC BY-NC-ND

Abstracted by: EBSCOhost, Electronic Journals Service (EJS),

Google Scholar, Directory of Open Access Journals (DOAJ),

Journal Seek, Scientific Commons,

Food and Agricultural Organization (FAO), CABI and Scopus

\author{
Journal of Agricultural Extension \\ Vol. 21 (3) October, 2017 \\ ISSN(e): 24086851; ISSN(Print); 1119944X \\ http://journal.aesonnigeria.org \\ http://www.ajol.info/index.php/jae \\ Email: editorinchief@aesonnigeria.org
}

farming Housholds in Kwara State, Nigeria. Production, Agriculture and Technology 6(2), 1 - 14

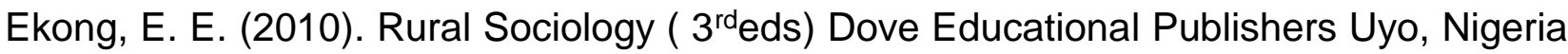
PP $1-425$

Haggblade, S.; Hazell, P. and Reardon, T. (2010). The Rural Farm Economy: Prospects for growth and poverty reduction. World Development, 38 (10): $1429-1441$.

National Population Commission (NPC), 2007: A Blue print on 2006 National Census of Nigeria.

National Root Crop Research Institute ( NRCRI) (1990) Annual Report, Umudike, Umuahia, Nigeria.

Obinna, L. O. (2014): Assessing the Benefits of Non- farm and Farm Activities Among Rural Dwellers in Ohafia and Umuahia Agricultural Zones of Abia State, Nigeria. Nigerian Journal of Agriculture, Food and Environment 10 (4) 106 - 111 December, 2014.

Olanipekun, A. A. and Kuponiyi, F. A. (2010). The Contribution of Livelihood Diversification to Rural Households Welfare in Ogbomoso Agricultural Zone of Oyo State, Nigeria. NJRS Vol. 11, No 2, December 2010, Pp 18 - 26

Ravallion, M. and Sangraula, C. S. (2009). "Premium Dollar a day" The World Bank Economic Review, 23 (2): 163 - 184.

Reardon, T.; Berdegue, J.; Barrett, C. B. and Stamoutis, K. (2007). Household Income Diversification into Rural Economy: Opportunities and Threats in the Developing World, pp 141 - 182

Saliu, O. J. and Adedayo, F. H. (2010). Non - Farm Income and Technology Adoption among Rural Farmers in Yagba East Local Government Area of Kogi State, Nigeria, NJRS Vol. 11, December 2010, Pp $50-57$

Streeten, F. (1979). First Thing First, Meeting Basic Human Needs in Developing Countries: Boulder: West view Press.

World Bank (1996) Nigeria: Poverty in the midst of plenty: The Challenges of Growth with Exclusion" A World Bank Development report 1996 